\title{
Application of Advanced Reservoir Characterization, Simulation, and Production Optimization Strategies to Maximize Recovery in Slope, and Basin Clastic Reservoirs, West Texas (Delaware Basin)
}

\author{
Quarterly Report \\ April 1 - June 30, 1998
}

By:
Shirley P. Dutton

Work Performed Under Contract No.: DE-FC22-95BC14936

For

U.S. Department of Energy

Office of Fossil Energy

Federal Energy Technology Center

P.O. Box 880

Morgantown, West Virginia 26507-0880

By

Bureau of Economic Geology

The University of Texas at Austin

University Station, Box X

Austin, Texas 78713-7508 


\section{Disclaimer}

This report was prepared as an account of work sponsored by an agency of the United States Government. Neither the United States Government nor any agency thereof, nor any of their employees, makes any warranty, express or implied, or assumes any legal liability or responsibility for the accuracy, completeness, or usefulness of any information, apparatus, product, or process disclosed, or represents that its use would not infringe privately owned rights. Reference herein to any specific commercial product, process, or service by trade

name, trademark, manufacturer, or otherwise does not necessarily constitute or imply its endorsement, recommendation, or favoring by the United States Government or any agency thereof. The views and opinions of authors expressed herein do not necessarily state or reflect those of the United States Government or any agency thereof. 


\section{TECHNICAL PROGRESS REPORT}

Title:

Cooperative Agreement No.:

Institution:

Date of Report:

Award Date:

Anticipated Completion Date for this Budget:

Government Award for this Budget Period:

Program Manager:

Principal Investigator:

Contracting Officer's Representative:

Reporting Period:
APPLICATION OF ADVANCED RESERVOIR

CHARACTERIZATION, SIMULATION, AND PRODUCTION OPTIMIZATION STRATEGIES TO MAXIMIZE RECOVERY IN SLOPE AND BASIN CLASTIC RESERVOIRS, WEST TEXAS (DELAWARE BASIN)

DE-FC22-95BC14936

Bureau of Economic Geology

The University of Texas at Austin University Station, Box $X$

Austin, Texas 78713-7508

J uly 31, 1998

March 31, 1995

J une 30, 1999

$\$ 1,248,033$

Daniel Ferguson

Shirley P. Dutton

Daniel Ferguson

April 1, 1998 - J une 30, 1998 


\section{OBJ ECTIVES}

The objective of this Class 3 project is to demonstrate that detailed reservoir characterization of slope and basin clastic reservoirs in sandstones of the Delaware Mountain Group in the Delaware Basin of West Texas and New Mexico is a cost effective way to recover a higher percentage of the original oil in place through strategic placement of infill wells and geologically based field development. Project objectives are divided into two main phases. The original objectives of the reservoir-characterization phase of the project were (1) to provide a detailed understanding of the architecture and heterogeneity of two representative fields of the Delaware Mountain Group, Geraldine Ford and Ford West, which produce from the Bell Canyon and Cherry Canyon Formations, respectively, (2) to chose a demonstration area in one of the fields, and (3) to simulate a $\mathrm{CO}_{2}$ flood in the demonstration area.

The Bureau's industry partner for the initial Phase 1 of the project was Conoco, Inc.. After the reservoir characterization and simulation of an area at the northern end of the Ford Geraldine unit were completed, Conoco decided not to proceed to Phase 2, installation of a $\mathrm{CO}_{2}$ flood in the demonstration area. This decision by Conoco provides an opportunity for a more extensive field demonstration in East Ford field, with Orla Petco as the industry partner. East Ford field is immediately adjacent to the Ford Geraldine unit and produces from the same Ramsey sandstone channel. Phase 1 of the project has been expanded to include reservoir characterization of East Ford field. This additional reservoir-characterization task provides an excellent opportunity to test the transferability of the geologic model and log-interpretation methods developed during reservoir characterization of the Ford Geraldine unit to another Delaware sandstone field.

The objectives of the implementation phase of the project remain the same, to (1) apply the knowledge gained from reservoir characterization and simulation studies to increase recovery from a demonstration area, (2) demonstrate that economically significant unrecovered oil can be recovered by a $\mathrm{CO}_{2}$ flood of the demonstration area, and (3) test the accuracy of reservoir characterization and flow simulation as predictive tools in resource preservation of mature fields. The goal is to develop a geologically designed $\mathrm{CO}_{2}$ flood and well-completion program in a representative Delaware Sandstone field that can serve as a model for other fields in the play. Through technology transfer, the knowledge gained in this study can be applied to increase production from more than 100 other Delaware Mountain Group reservoirs.

\section{SUMMARY OF TECHNICAL PROGRESS}

Conoco, Inc., the industry partner for this project through December, 1997, decided not to proceed to a Phase 2 field demonstration in the Ford Geraldine unit. The decision by Conoco, Inc. provides an opportunity for a different, and more definitive, Phase 2 field demonstration in East Ford field, with Orla Petco as the industry partner. Orla Petco, Inc. is the operator of East Ford field, which is immediately adjacent to the Ford Geraldine unit and produces from the same Ramsey sandstone channel. The Bureau and Orla Petco submitted a revised statement of work to extend the reservoir characterization phase of the project to include East Ford field. The revised statement of work was approved at the end of the quarter.

Reservoir characterization of East Ford field will be necessary before moving to the fielddemonstration phase. Reservoir characterization of this new field will provide an excellent opportunity to test the transferability of the information and methodologies that were developed during the Ford Geraldine study to another Delaware Mountain Group field with less abundant data. It is anticipated that information on depositional processes, geometries, and dimensions of Bell Canyon sandstone bodies developed from the outcrop study (Dutton and others, 1997 and 
1998) will apply to Ford East field equally well as to the reservoirs at the Ford Geraldine unit. Furthermore, the methods of petrophysical analysis developed to work with the 1950's vintage logs from the Ford Geraldine unit (Asquith and others, 1997; Dutton and others, 1997) should be applicable in East Ford field as well.

The mid-project decision point will come at the end of the expanded Phase 1 . Upon the successful completion of Phase 1 and approval by DOE, the project will proceed to the Phase 2 demonstration, a $\mathrm{CO}_{2}$ flood in East Ford field. The original objectives of the field demonstration-assessment of the effectiveness of $\mathrm{CO}_{2}$ flooding to improve recovery in a mature Ramsey sandstone field-will be accomplished in a more definitive test than would have been possible in the Ford Geraldine unit. Orla Petco began a $\mathrm{CO}_{2}$ flood in the Ramsey sandstone in East Ford field in J uly, 1995. Orla Petco will make available to the DOE project all of the injection and production data generated since the flood was initiated in J uly, 1995. By the end of Phase 2, more than four years of $\mathrm{CO}_{2}$ flood data will be available, which will allow a more complete evaluation of the success of the flood and a better comparison to the predictions made on the basis of the reservoir characterization and simulation.

\section{TECHNOLOGY TRANSFER}

The draft annual report for the third year of the project (Dutton and others, 1998) was submitted for review. Upon receiving the review comments, the report will be revised and the final report submitted.

One presentation based on the project was given this quarter, as follows:

Dutton, S. P., Barton, M. D., and Cole, A. G., 1998, Ramey Sandstone Channel-Levee and Lobe Deposits: Deep-Marine Clastic Reservoirs in the Bell Canyon Formation, Delaware Basin, Texas (abs.): 1998 AAPG Annual Convention, Extended Abstracts, v. 1, p. A173. Oral presentation given by S. P. Dutton at the 1998 Annual Meeting of the American Association of Petroleum Geologists in Salt Lake City, Utah, May 19, 1998.

\section{PLANNED ACTIVITIES}

Reservoir characterization of East Ford field will begin during the next quarter. Well files containing well logs, completion and workover history, pressure and production tests, and core-analysis results will be copied from Orla Petco files and organized and assembled at UT/ BEG offices in Austin. Production records will be copied from Orla Petco files. Production data will be loaded into a computer data base for manipulation and mapping. Well logs will be digitized and stored in a computer data base.

Reservoir characterization of East Ford field will include (1) correlating and subdividing the high-order cycle that includes the Ramsey sandstone reservoir interval; (2) mapping the geometry of reservoir sandstone bodies and bounding siltstones; and (3) constructing a depositional model for East Ford field. Information about Bell Canyon sandstones previously gathered from well exposed outcrops (Dutton and others, 1997) and from the abundant core and log data in the Ford Geraldine unit will guide the geologic interpretation of East Ford field. 


\section{REFERENCES}

Asquith, G. B., Dutton, S. P., Cole, A. G., Razi, M., and Guzman, J . I., 1997, Petrophysics of the Ramsey Sandstone, Ford Geraldine Unit, Reeves and Culberson Counties, Texas: West Texas Geological Society Publication No. 97-102, p. 61-69.

Dutton, S. P., Asquith, G. B., Barton, M. D., Cole, A. G., Gogas, J ., Malik, M. A., Clift, S. J ., and Guzman, J. I., 1997, Application of advanced reservoir characterization, simulation, and production optimization strategies to maximize recovery in slope and basin clastic reservoirs, West Texas (Delaware Basin): The University of Texas at Austin, Bureau of Economic Geology, annual report prepared for the U.S. Department of Energy, $187 \mathrm{p}$.

Dutton, S. P., Barton, M. D., Malik, M. A., Asquith, G. B., Guzman, J . I., Clift, S. J ., Cole, A. G., 1998, Application of advanced reservoir characterization, simulation, and production optimization strategies to maximize recovery in slope and basin clastic reservoirs, West Texas (Delaware Basin): The University of Texas at Austin, Bureau of Economic Geology, annual report prepared for the U.S. Department of Energy, 88 p. 